\title{
Editorial 24/4: Electronic markets and business models
}

\author{
Rainer Alt • Hans-Dieter Zimmermann
}

Published online: 25 November 2014

(C) Institute of Information Management, University of St. Gallen 2014

Dear readers of Electronic Markets,

Almost 15 years have passed since Electronic Markets published the first special issue on business models in 2001. This was a time where business strategists had difficulties in systematically explaining the essence, logic and ingredients of business models. Compared to the long-term timing that was prevalent in traditional thinking on business strategies, Internet thinkers and practitioners brought a new concept more or less overnight into the business world and caught many strategists by surprise. This does not mean that the new term was always used precisely and with sufficient "meat". As described by Magretta (2002, p.86), business models were "one of the great buzzwords of the Internet boom, routinely invoked, [...] to glorify all manner of half-baked plans". Business model definitions emerged in the late 1990s and we are proud that one of the earliest definitions available was published by Paul Timmers from the European Commission in volume 8 of Electronic Markets. He conceived a business model as "an architecture for the product, service and information flows, including a description of the various business actors and their roles; and a description of the potential benefits for the various business actors; and description of the sources of revenues." (Timmers 1998, p.4). It turns out that this definition was used widely and is still referenced today.

Remarkably, the article has received the highest number of downloads and citations of all Electronic Markets articles so far. Following Harzing the article has scored a total of 2'283

\footnotetext{
R. Alt $(\bowtie)$

Information Systems Institute, University of Leipzig,

Grimmaische Str. 12, 04109 Leipzig, Germany

e-mail: rainer.alt@uni-leipzig.de

H.-D. Zimmermann

FHS St. Gallen, University of Applied Sciences,

Rosenbergstrasse 59, 9001 St. Gallen, Switzerland

e-mail: hansdieter.zimmermann@fhsg.ch
}

citations (as per October 2014), which is considerably more than the second ranked article on citizen adoption of eGovernment (Warkentin et al. 2002) with a total of 434 citations. Another contribution on business models ranks third with some 404 citations. This is the preface to Electronic Markets' first special issue on business models (Alt and Zimmermann 2001), which not only introduced the four research papers of the special issue at that time, but also aimed at summarizing existing knowledge in business model research. The paper started by analyzing the usage of the term "business model" in various databases and revealed only a limited proliferation. This has changed considerably as Table 1 shows with a sample of the same searches today and a total of 600 mentions in Electronic Markets papers in various contexts of business models since. Another analysis on the number of papers published in Web of Science journals even revealed some 4'000 mentions (DaSilva and Trikman 2013). It is astonishing that despite publications including the title term "business model" have attracted many writers, Teece (2010, p.192) concludes that the "paucity of literature (both theoretical and practical) on the topic is remarkable, given the importance of business design, particularly in the context of innovation." In view of this statement, let us take the opportunity of this editorial to reflect on some aspects of the business model construct.

First, business models are accepted as important elements in the construction of an organization's strategic positioning and offerings in the market. Following the principle of models, they reduce real world complexity by representing only relevant design elements for a specific design purpose (Baden-Fuller and Morgan 2010). All other intricacies existent in the real world, which might be relevant for other purposes, should be suppressed. Thus, business models are helpful in mapping the specific ingredients and mechanics of understanding how a business works. Due to the obvious link to business strategy, a question that was raised is how business 
Table 1 Search for term "Business Models" in topics (as per October 2014, values for 2001 in brackets)

\begin{tabular}{llll}
\hline & Title search exact & Title search associated terms & Search keyword \\
\hline Emerald & $4{ }^{\prime} 149(1)$ & $82^{\prime} 541(-)$ & $38(3)$ \\
Ebsco & $252(5)$ & $1^{\prime} 024(12)$ & (n.a.) \\
Catchword & $329(4)$ & $796(3)$ & $10^{\prime} 941$ (3) \\
Gartner group & $106(32)$ & 242 (n.a.) & (n.a.) \\
Forrester research & $997(2)$ & $5^{\prime} 960$ (n.a.) & (n.a.) \\
Amazon.com & $199^{\prime} 233(6)$ & $72^{\prime} 428(2)$ & (n.a.) \\
\hline
\end{tabular}

models differ from strategy itself. Is business strategy a prerequisite and input for the business model or is business strategy an outcome of a business model? For example, Teece (2010, p.180) notes that "selecting a business strategy is a more granular exercise than designing a business model." In that vein, Veit et al. (2014, p.46) recognize a mutual relationship between both terms: "while strategy focuses on how to prevail over competitors, the business model depicts the logic of value creation and the effective coordination of business resources". Thus, being more generic in nature, business strategy defines how a company differentiates itself in which markets as well as via which products. A business model may be viewed as an interface between the business strategy and the business process layers coping with the high dynamics in the digital business world (see dimension 1 "positioning" of business model research in Fig. 1): "It intersects with the business strategy as well as the business processes including their supportive IS [...]. These intersections represent two crucial transitional points to be followed by business organizations." (Al-Debei and Avison, 2010, p.370). What is often overseen is that strategy should also formulate guidelines for how business models are developed.

Second, business model research has also contributed to the understanding of a business model's building blocks or design elements. The 2001 editorial already suggested a framework with six constituting elements of business models based on an analysis of all articles on business models in the first nine volumes of Electronic Markets (see dimension 2 "Building blocks" in Fig. 1). Mission, structure, processes, revenues, legal issues and technology were identified as generic elements of a business model. Many frameworks have emerged since, but despite slight variations, the main categories still prevail. For example, Seidenstricker et al. (2014, p.104) distinguish between enablers (technologies, channels, network/partners), a structure element (value chain, processes) and results (value proposition, revenues). Although information technology (IT) itself is not a necessary ingredient of business models, many of the existing and future business models are highly dependent on how IT is used to enhance the other business model elements. In particular, this applies to electronic markets and networked value chains which inherently rely on IT. The various stages in the evolution of electronic commerce technologies (Alt and Zimmermann 2014) present a view on the potentials, which may be explored in different electronic business models.

Third, different typologies for business models emerged based on the specific configuration of the business model elements (Baden-Fuller and Morgan 2010). Among the examples are containerization and the banking network Swift (Teece 2010, p.179), freemium models (Wagner et al. 2014) as well as open business models (Chesbrough 2007). Following the work of Baden-Fuller and Morgan (2010, p.161) the identification of these "ideal types" is "not a straightforward task" and may either be initiated top-down via conceptual and theoretical work - thus leading to typologies - or bottom-up via observation and empirical work - thus leading to taxonomies. Timmers (1998, p.4) applied a mixed procedure in his article, since based on the observation of various businesses he suggested a typology of eleven business models for electronic markets and classified them depending on their degree of innovation and their scope of functional integration. Clearly, these "ideal types" are generic in nature and decision makers need to meet the challenge of crafting individual business models depending on their strategies (see dimension 3 "Typology" in Fig. 1). This explains why one business model hardly exactly matches other apparently similar competing business models.

Fourth, the process and the tools used for business modeling have become a path of investigation. For example, Girotra and Netessine (2014) compile a set of recommendations and guidelines, which should be considered when developing business models. Seidenstricker et al. (2014, p.105) propose a three phase methodology for developing business models: after defining the aim and identifying the potential field, ideas for new business models should be generated and subsequently the prototypes should be assessed. This area emphasizes that business model generation and refinement is an ongoing task that also calls for appropriate tools. Here, IT comes in a second time after being an enabler for business models: frameworks and typologies may be implemented on a business model workbench, which supports the configuration process of a new business model. In analogy to business process modeling as well as systems design, notations have emerged for systematically sketching business models. Among the examples are e3value (Gordijn and Akkermans 2001) as well as the Business Model Canvas (Osterwalder and Pigneur 2010). 
Fig. 1 Generic elements of business models and business strategy

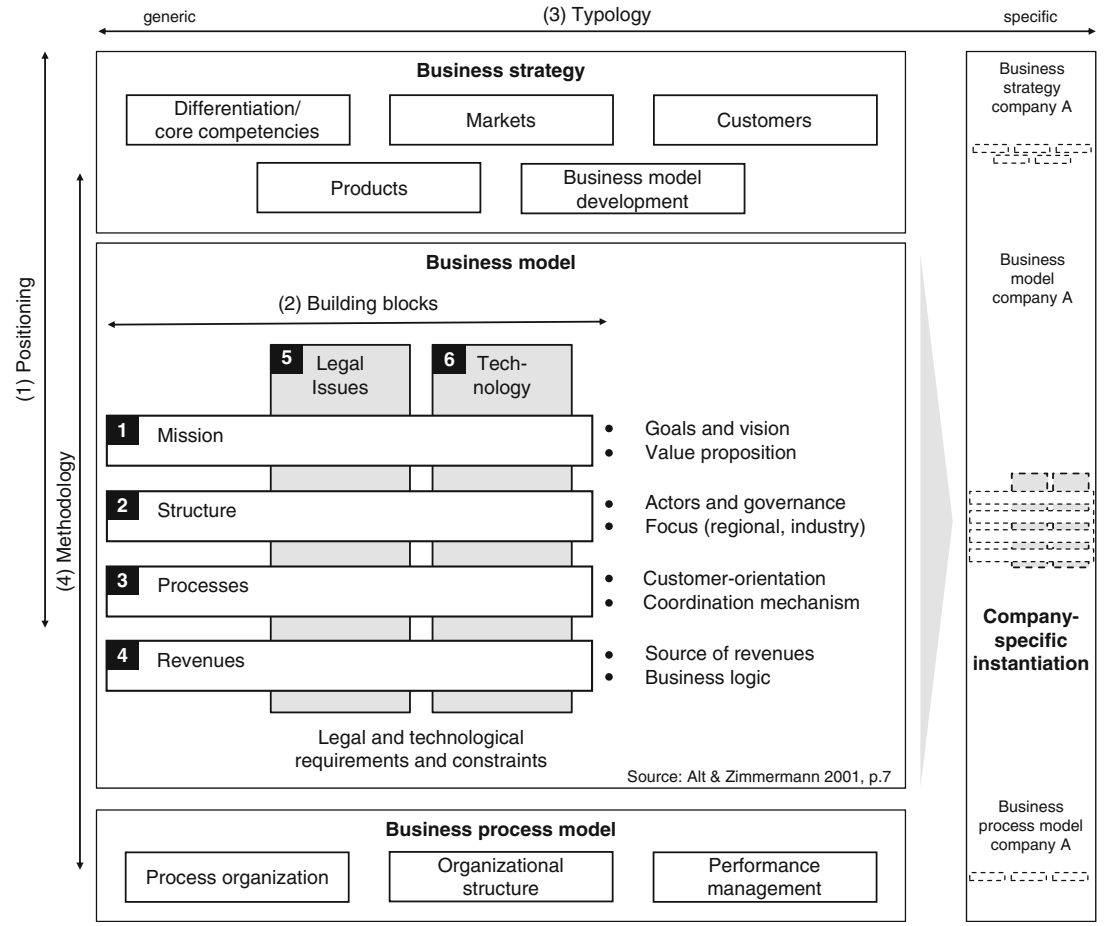

These four aspects may explain why business models have become an important research topic within the area of electronic markets and networked business. Typically, they require the collaboration of multiple actors within a network and a shared understanding of the key elements of the joint business model. The identification of each partner with the identity of the network may be critical for the success of the joint outcome. Since business models are more detailed than strategy, they strongly support the discussion of critical design aspects and "nasty questions" among the participating actors. However, the configuration of each business model design element is not a unique, one-off undertaking, but also calls for a continuous monitoring on whether changes have occurred regarding individual elements and the entire system of design elements. In particular, technological potentials, such as mobile, social or cloud technologies as well as new or more widespread standards, may evolve and change the coherence and value of the business model. This might also impact existing typologies of business models with new types becoming apparent and others becoming obsolete. However, beyond the pure typology of business models, research in this domain still falls short on evaluations regarding the question of which models might work within a certain setting. The same also applies for methodologies that not only support the modeling of business models, but which also allow for an integrated specification of strategy, business model, processes and systems (see dimension 4 "Methodology" in Fig. 1).

In summary, we feel that although business model research shows a record of many publications, ample room for further investigation remains. We have taken this opportunity to reflect on achievements as well as future questions with three well-known scholars in interviews, which are included in this issue as invited articles. We highly appreciate the time of Paul Timmers, Alexander Osterwalder and Hubert Österle for sharing their thoughts with us. As introduced earlier, Paul Timmers is widely acknowledged as one of the earliest authors on business models. His seminal article in Electronic Markets has become known for the definition of business models as well as the typology of business models for electronic commerce. In his interview, Paul not only shares his motivation on writing this article, but also on how his thinking on business models has developed in the sixteen years since its publication. Alexander Osterwalder's contribution is six years younger. In his doctoral thesis (Osterwalder 2004), he developed an ontology for business models, which eventually laid the foundations for a well-known strategic concept, known as the Business Model Canvas. However, he was also successful in building a business around business models. In his interview, Alexander shares his exciting views on the role of academic work and the developments, which are still ahead of us in the area of business models.

The third interview is with our editor-in-chief Hubert Österle. Having been a professor for 34 years, he has always aimed at bridging the alleged gap between academia and practice. His statements shed light on how the focus of IT has moved from the company to the consumer and the fundamental transformation as well as opportunities still ahead. His expectations include new business models around well-being, health and life quality, which almost seamlessly bring us to the topic of the four special theme articles in this issue. Whichever 
definition of the term business model we look at, generating value for the user or the customer remains a key goal. We are grateful to Hubert and his guest editors Jan Marco Leimeister and Steven Alter that they initiated the special issue on "Digital Services for Consumers". The section comprises four papers, which all focus on the end user's perspective on innovative digital services. The guest editors will introduce each paper individually in their elaborated preface (Leimeister et al. 2014). We would like to thank the guest editors and all reviewers who were involved in putting together this compelling special issue.

Finally, we wish to use this opportunity to extend our thanks to the members of our editorial team. This goes to Dorothee Elsner who handled the tasks in the editorial office for one year starting summer 2013 before going into parental leave. First Nadja Schubert and then Christian Hrach took over the duties and challenges of this role, which is more than vital for Electronic Markets. We highly value the contribution of all three of them! In August 2014, Carsta MilitzerHorstmann joined the team as new Executive Editor, who is now responsible for the daily business at Electronic Markets. Carsta holds a M.Sc. from San Diego State University as well as a diploma in business administration from the European University Viadrina at Frankfurt/Oder, Germany. She will finish her Ph.D. at the University of Fribourg, Switzerland, in entrepreneurship and has already shown her high dedication to Electronic Markets. In case you have any suggestions or questions to Electronic Markets please do not hesitate to contact her.

Best regards from Leipzig and St. Gallen,

Rainer Alt, Hans-Dieter Zimmermann

\section{References}

Al-Debei, M. M., \& Avison, D. E. (2010). Developing a unified framework of the business model concept. European Journal of Information Systems, 19(3), 359-376. doi:10.1057/ejis.2010.21.
Alt, R., \& Zimmermann, H. D. (2001). Introduction to special section business models. Electronic Markets, 11(1), 3-9. doi:10.1080/ 713765630.

Alt, R., \& Zimmermann, H. D. (2014). Electronic Markets and general research. Electronic Markets, 24(3), 161-164. doi:10.1007/s12525014-0163-9.

Baden-Fuller, C., \& Morgan, M. S. (2010). Business models as models. Long Range Planning, 43(2-3), 156-171. doi:10.1016/j.1rp.2010.02.005.

Chesbrough, H. (2007). Open business models. Boston: Harvard Business School Press.

DaSilva, C.M., \& Trikman, P. (2013). Business model: What It is and what it is not. Long Range Planning 43, doi: 10.1016/j.lrp.2013.08.004.

Girotra, K., \& Netessine, S. (2014). Four paths to business model innovation. Harvard Business Review, 92(7), 96-103.

Gordijn, J., \& Akkermans, H. (2001). Designing and evaluating ebusiness models. IEEE Intelligent Systems, 16(4), 11-17. doi:10. $1109 / 5254.941353$.

Leimeister, J.M., Österle, H., \& Alter, S. (2014). Preface on „Digital services for consumers“. Electronic Markets, 24(4). doi:10.1007/ s12525-014-0174-6.

Osterwalder, A. (2004). The business model ontology - a proposition in a design science approach. Doctoral thesis. Université de Lausanne.

Osterwalder, A., \& Pigneur, Y. (2010). Business model generation: a handbook for visionaries, game changers, and challengers. New York: Wiley.

Seidenstricker, S., Scheuerle, S. \& Linder, C. (2014). Business model prototyping - using the morphological analysis to develop new business models. Procedia - Social and Behavioral Sciences, 148, 102-109, doi: 10.1016/j.sbspro.2014.07.023.

Teece, D. J. (2010). Business models, business strategy and innovation. Long Range Planning, 43(2-3), 172-194. doi:10.1016/j.lrp.2009.07.003.

Timmers, P. (1998). Business models for electronic commerce. Electronic Markets, 8(2), 3-8, doi: 10.1080/10196789800000016.

Veit, D., Clemons, E., Benlian, A., Buxmann, P., Hess, T., Kundisch, D., Leimeister, J. M., Loos, P., \& Spann, M. (2014). Business models - an information systems research agenda. Business \& Information Systems Engineering, 6(1), 45-53. doi:10.1007/s12599-013-0308-y.

Wagner, T.M., Benlian, A. \& Hess, T. (2014). Converting freemium customers from free to premium - The role of perceived premium fit in the case of music as a service. Electronic Markets, 24(4), doi: 10.1007/s12525-014-0168-4.

Warkentin, M., Gefen, D., Pavlou, P. A., \& Rose, G. M. (2002). Encouraging citizen adoption of e-government by building trust. Electronic Markets, 12(3), 157-162. doi:10.1080/ 101967802320245929. 